\title{
Franchisors on the Financing and Other Problems of Prospective Franchisees
}

\begin{abstract}
A M Smit
Potchefstroom Business School, Potchefstroom University for Christian Higher Education
\end{abstract}

\section{ABSTRACT}

The current high unemployment rate and the need to develop the SME sector in South Africa, has highlighted the franchise sector as a possible generator of employment and wealth. Certain problems in the SME sector, for example the lack of financing, were identified and investigated from the viewpoint of the franchisor. This study attempts to analyse the general problems that prospective franchisees are confronted with and then focuses on the more specific problems regarding financing as experienced by the prospective franchisees.

JEL M13, M20

\section{BACKGROUND AND MOTIVATION FOR THE RESEARCH}

The development of the small business sector is one of the critical areas in the economy of South Africa. The small business sector plays an important part in the economic and social development of the country and can contribute substantially to job creation.

A lively small business sector is regarded as a prerequisite for fast growth and economic development in South Africa (Thomas, 1995: 13). The development of the small business sector is also regarded as a mechanism allowing formerly disadvantaged groups access to economic opportunities. It may thus contribute to the redistribution of income and wealth.

In order to achieve success regarding the goals, as expounded in Part 4 of the SMME White paper, twelve aspects identified in the White paper deserve attention. One of the most important aspects, which is directly relevant for this survey, is the accessibility of financing for the small business sector. The general feeling of entrepreneurs and other institutions supporting the small business sector is that access to financing at affordable interest rates is one of the deciding factors for the success of the small business enterprise (Thomas, 1995: 21). 
Several studies have been undertaken to determine the reasons for failure of small business enterprises. Amongst the most important reasons pointed out are the lack of managerial capabilities such as planning and decision making and experience of the entrepreneur (Gaskill, van Auken et al., 1993: 25). Many other reasons for the failure of the small business enterprises arise from this, for example:

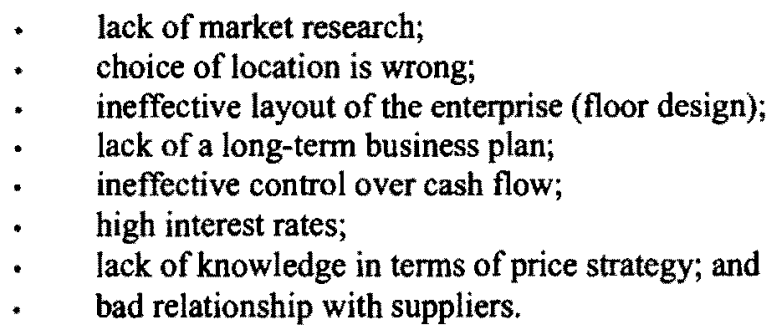

A kind of enterprise containing some of the elements to address abovementioned deficiencies is the franchise enterprise. Franchising is also considered a good option for South Africa to create work and establish new enterprises (Holmes, 1994: 27). In view of tendencies in the South African economy, it seems as if small business enterprises and especially the franchise trade can play a part in creating entrepreneurs. It can also result in the creation of work opportunities, which in turn can contribute to economic growth.

The international success record of the franchise trade makes research on this relatively young form of business not only topical but also essential. American statistics show a 90 per cent success rate of all franchise businesses that are established (African Business, 1993: 24), while 80 per cent of other types of small business enterprises fails. Franchising presently grows at a rate of 10 per cent per year and represents 5.6 per cent of the trade activities in the world economy. In the US, the franchise business was already labeled the success story of the nineties, with more than 600000 franchise enterprises providing an annual turnover of $\$ 758$ milliard (De Villiers, 1994: 53).

Since 1994, the number of franchised systems in South Africa has increased threefold. Between 1994 and 1998 growth was exponential; the growth has slowed somewhat over 1999 and 2000 . This can be attributed to high interest rates and a shift in consumption patterns. As a result, the nature and type of businesses, which usually expand on a franchise basis, are changing (Gordon, 2000: 2). 
Given the above statistics, the growth in the franchise trade worldwide and the need for growth and development in the South African economy, a study on the aspects which can foster the trade locally is of importance to South Africa.

\section{PROBLEM-SETTING}

In 1994, Parker Gordon Associates undertook the first formal investigation of the franchise business in South Africa (Parker Gordon Assoc., 1995: 1). In the survey, it was determined that 41.8 per cent of the franchise holders confirmed that their prospective franchisees experienced difficulty obtaining financing. In their study, the problems that the prospective franchisee experienced in terms of financing were the following:

- lack of capital for collateral;

- insufficient own capital;

- banks and other financial institutions do not understand the concept of franchising;

- apart from commercial banks there are inadequate other financing sources accessible to the prospective franchisee.

This study investigates and analyses financing constraints experienced by a prospective franchisee in view of the above-mentioned aspects.

\section{PURPOSE OF THE STUDY}

The main purpose of this study is to identify financing constraints and thus to facilitate financing for prospective franchisees. This can stimulate growth in the small business sector, enhance job creation and result in general economic progress.

\section{RESEARCH METHODOLOGY}

The study is constructed as follows:

A literature review is conducted, which review concentrates on certain aspects of financing and more specific the financing of small business enterprises. The empirical study focuses on the present financing practice of the small business enterprises with special reference to franchises. 
The analytical units of the population on which the research is based consist of all the franchisors registered with the Franchise Association of Southern Africa (FASA). According to The Franchise book of Southern Africa of 1998, there were 358 franchised systems in operation in South Africa (Stone, 2000: 46). According to Louw, the executive director of FASA, about 70 to 75 p.r cent of all franchisors in Southern Africa are registered with FASA. The top 100 franchisors were selected on account of their turnover and the number of outlets. According to Gorden (2000: 4) the average number of outlets or business units per franchised system is 49 . The data was collected by means of questionnaires sent by post and/or fax. There were 43 responses and the response rate was 43 per cent.

\section{RESULTS}

The Problems Experienced by the Franchise Trade in Terms of Financing and Otherwise

The first part of the questionnaire deals with the general problems experienced by the small business sector. Specific financing problems and the contribution that can be made by the trade to economic progress are also addressed.

\section{General Problems Experienced by the Small Business Sector}

Studies in other developed and developing countries suggest that the small business sector can contribute to the advancement of the economy and job creation (Ruiters, 1996: 8). Despite this, there is still scope for extensive development in this sector in South Africa and some problems persist.

In question 1 of the questionnaire, a list of possible problems is submitted to the respondents to which items could be added and then evaluated on a scale from 1 to 4 . A scale mark of 4 indicates a problem generally experienced and 1 a problem that never occurs. The results are presented in Table 1.

The problems indicated by the respondents as problems experienced generally and often are focused on next. The first problem singled out is the lack of knowledge and managing experience. Here, 11.6 per cent of the respondents indicated it as a general problem and 39.5 per cent a problem occurring often; the arithmetic mean is 2.56 .14 per cent indicated inaccessibility of financing as a problem occurring always and 39.5 per cent as a problem occurring often; the arithmetic mean is 2.53 . 
Among the other problems added to the list, lack of training is a problem occurring often, according to 4.7 per cent of the respondents.

\section{Table 1 Problems experienced by the small business sector}

\begin{tabular}{|c|c|c|c|c|c|c|c|c|c|}
\hline \multirow{2}{*}{$-\ldots$} & \multicolumn{2}{|c|}{$\begin{array}{c}\text { Never } \\
1\end{array}$} & \multicolumn{2}{|c|}{$\begin{array}{c}\text { Sometimes } \\
2 \\
\end{array}$} & \multicolumn{2}{|c|}{$\begin{array}{c}\text { Often } \\
3 \\
\end{array}$} & \multicolumn{2}{|c|}{$\begin{array}{c}\text { Generally } \\
4 \\
\end{array}$} & \multirow[t]{2}{*}{$\begin{array}{l}\text { Arithm. } \\
\text { mean }\end{array}$} \\
\hline & $\mathbf{F}$ & $\%$ & I & $\%$ & f & $\%$ & $\mathbf{r}$ & $\%$ & \\
\hline I ach of millature & 7 & 16.3 & 25 & 58.1 & 8 & 18.6 & 3 & 7.0 & 2.16 \\
\hline $\begin{array}{l}\text { Lesch of hous ledge and } \\
\text { managing experience }\end{array}$ & 3 & 7.0 & 18 & 41.9 & 17 & 39.5 & 5 & 11.6 & 2.56 \\
\hline The market is saturated & 16 & 37.2 & 19 & 44.2 & 7 & 16.3 & 1 & 2.3 & 1.84 \\
\hline $\begin{array}{l}\text { Lack of market } \\
\text { research }\end{array}$ & 6 & 14.0 & 21 & 48.8 & 14 & 32.6 & 2 & 4.7 & 2.28 \\
\hline $\begin{array}{l}\text { Inaccessibility to } \\
\text { financing }\end{array}$ & 6 & 14.0 & 14 & 32.6 & 17 & 39.5 & 6 & 14.0 & 2.53 \\
\hline Other & 40 & 93.0 & 1 & 2.3 & 2 & 4.7 & - & - & - \\
\hline
\end{tabular}

The lack of knowledge and managing experience and the inaccessibility of financing are the most prominent problems of the small business sector. The franchising concept offers the advantage that the entrepreneur is not left to its own devices but can rely on the support of the franchisor. Part of the franchise package is the supply of trade manuals and training by the franchisor. The problem indicated above as a lack of knowledge and managing experience can be obviated by the franchising concept.

\section{Problems Experienced by the Prospective Franchisee}

The purpose of question 2, is to identify which problems prospective franchisees experience in establishing an enterprise and then to rate it on a scale from 1 to 4 . The results are shown in Table 2. The first part of the column shows the frequency, which is then expressed and a percentage in the second part of the column.

14 per cent of the respondents indicated financing as a problem occurring always, while 41.9 per cent mentioned that financing problems occur often. The next problem often encountered, is the lack of managing experience. 14 per cent also indicated that financing problems are never experienced. 
Table 2 Problems experienced by the prospective franchisee

\begin{tabular}{|l|c|c|c|c|c|c|c|c|}
\hline & \multicolumn{2}{|c|}{$\begin{array}{c}\text { No problem } \\
\end{array}$} & \multicolumn{2}{|c|}{$\begin{array}{c}\text { Little/Seldom } \\
2\end{array}$} & \multicolumn{2}{c|}{$\begin{array}{c}\text { Often } \\
3\end{array}$} & \multicolumn{2}{c|}{$\begin{array}{c}\text { Always a } \\
\text { problem } \\
4\end{array}$} \\
\cline { 2 - 10 } & F & $\%$ & F & $\%$ & f & $\%$ & I & $\%$ \\
\hline $\begin{array}{l}\text { Lack of managing } \\
\text { experience }\end{array}$ & 6 & 14.0 & 22 & 51.2 & 14 & 32.6 & 1 & 2.3 \\
\hline Locality of the enterprise & 16 & 37.2 & 16 & 37.2 & 9 & 20.9 & 2 & 4.7 \\
\hline Crime & 19 & 44.2 & 17 & 39.5 & 4 & 9.3 & 3 & 7.0 \\
\hline Financing problems & 6 & 14.0 & 13 & 30.2 & 18 & 14.9 & 6 & 14.0 \\
\hline Other & 39 & 90.7 & 1 & 2.3 & 3 & 7.0 & - & - \\
\hline
\end{tabular}

Problems indicated under 'other' are difficulties in convincing the financier of the viability of the project and the lack of sufficient collateral. However, both these problems bear relation to financing. From the results it is clear that, although other problems such as crime and the location of the business are also mentioned as problems, these are not of the same magnitude as lack of managing experience and difficulties obtaining financing.

In question 3 the franchisor was asked to indicate whether some of his franchisees experience problems obtaining financing. The results are shown in Table 3.

Table 3 Financing problems

\begin{tabular}{|c|c|c|c|}
\hline \multicolumn{2}{|c|}{ YES } & \multicolumn{2}{c|}{ NO } \\
\hline F & $\%$ & f & $\%$ \\
\hline 28 & 65.1 & 15 & 34.9 \\
\hline
\end{tabular}

65.1 per cent of the respondents indicated that their franchisees encounter problems in obtaining financing. Financing related difficulties are among the gravest problems experienced by prospective entrepreneurs. 


\section{The Contribution of the Franchise Trade to the Economic Progress of the Country}

In question 4 the respondents were asked to indicate whether the franchise trade can contribute to the economic progress of the country. The results are reflected in Table 4.

Table 4 The contribution of the franchise trade

\begin{tabular}{|c|c|c|c|}
\hline \multicolumn{2}{|c|}{ YES } & \multicolumn{2}{c|}{ NO } \\
\hline F & $\%$ & f & $\%$ \\
\hline 42 & 97.7 & 1 & 2.3 \\
\hline
\end{tabular}

From the results above it would appear that 97.7 per cent of the respondents confirm that the franchise trade can contribute to economic progress. The franchise concept, and particularly the business format and method involved, contains inherent qualities that may surmount the weaknesses, giving rise to failures. This trade has great potential and is still under utilised. Parker \& Gordon (1995: 6) predict that franchising will increasingly be used in South Africa to furnish large markets with commodities. Feinstein, an authority on small business enterprises and franchises, also expresses the view that the possibilities offered by franchises are not fully exploited in South Africa (Feinstein, 1993: 1).

In question 5 , the respondents were asked to give their opinion with regard to the contribution the franchise trade could make to the upliftment of less privileged groups. The results are presented in Table 5.

Table 5 The contribution of the franchise trade to groups previously underprivileged

\begin{tabular}{|c|c|c|c|}
\hline \multicolumn{2}{|c|}{ YES } & \multicolumn{2}{c|}{ NO } \\
\hline F & $\%$ & f & $\%$ \\
\hline 40 & 93.0 & 3 & 7.0 \\
\hline
\end{tabular}

According to the results in Table 5,93 per cent of the respondents are of the opinion that the franchise trade can encourage economic activity of less privileged groups. A project to support prospective entrepreneurs in South Africa, the Black Integrated Commercial Support Network (BICSN) sponsored 
by the US Agency of International Development (US Aid) is currently in operation. Franchising is regarded as one of the methods of supporting black people effectively in establishing businesses (Anon., 1993: 24).

\section{Problems Regarding Financing as Experienced by Prospective Franchisees}

In question 6 , a list of problems experienced by prospective franchisees in terms of financing is submitted to respondents requesting them to identify how often these and other problems are experienced and to add information, if necessary. A scale mark of 4 indicates a problem occurring continuously and 1 a problem never experienced.

Inadequate own capital is singled out as a problem experienced always by 18.6 per cent of the respondents and by 58.1 per cent as a problem experienced often. The arithmetic mean is 2.93 .

Insufficient collateral is indicated as a problem always experienced by 27.9 per cent of the respondents. 34.9 per cent indicated lack of collateral as a problem often occurring. The arithmetic mean is 2.84 .

Table 6 Problems regarding financing as experienced by prospective franchisees

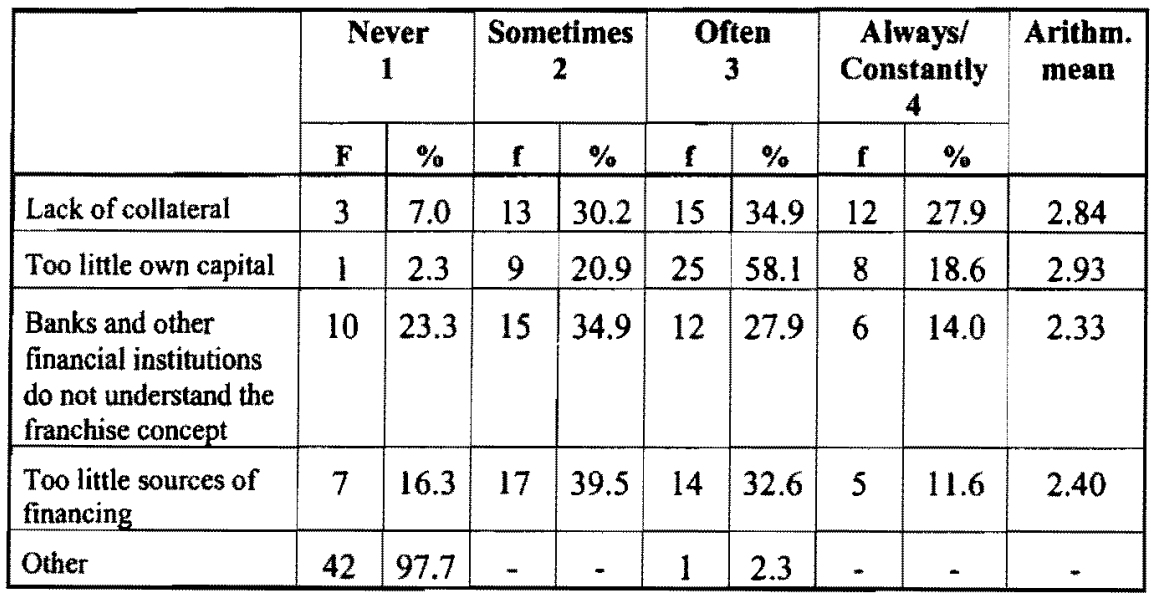

Regarding other problems, 14 per cent of the respondents are of opinion that banks and other financial institutions always fail to understand the franchise concept, while 27.6 per cent feel that the concept is often not understood. 
Furthermore, 32.6 per cent indicated that sufficient financing sources are often not available to the prospective franchisee.

The most prominent problems are inadequate own capital and collateral. These two problems are closely related; entrepreneurs have insufficient capital or other assets at his disposal to hedge against risks. The greatest part of the population has insufficient collateral at their disposal. In order to stimulate entrepreneurship, the establishment of own businesses and the small business sector in general, banks may consider a more compliant stand regarding the provision of collateral when evaluating an application for financing.

\section{CONCLUSIONS}

The lack of practical knowledge and managing experience, with an arithmetic mean of 2.56, and the inaccessibility of financing, with an arithmetic mean of 2.53 out of 4 , are considered as the most important problems experienced in the small business sector (Table 1).

In a next section, with regard to the same problems, the respondents were requested to single out the general problems experienced by prospective franchisees. In Table 2 the general problems the prospective franchisee experiences are reported. On an interval scale 14 per cent of the respondents indicated financing problems as a problem always occurring. An additional 41.9 per cent indicated that financing problems occur often. Lack of knowledge and managing experience is the problem appearing in the second place, as indicated.

Interesting conclusions may be drawn from a comparison of the above information. In the case of general problems experienced by the small business sector, lack of practical knowledge and managing experience appears prominent. In the case where the question was applicable to franchisees, a shift in emphasis is noticeable. Inaccessibility of financing was then shown to be the most prominent problem, followed by the lack of business knowledge and managing experience.

The above shift in emphasis can be explained as follows: It confirms one of the advantages of the franchise concept, namely that management skills and experience are transmitted from franchisor to franchisee. The franchising concept thus alleviates the problem of inadequate business skills and managing experience. 
It is in many instances more expensive to buy a franchise business; consequently there is a greater need of financing and therefore greater prominence is given to the financing problem. Having singled out the financing problem, the problem was further investigated by identifying which specific problems are experienced with regard to financing.

Table 6 shows the results of the franchisers' responses. Inadequate own capital and a lack of collateral, with an arithmetic mean of respectively 2.93 and 2.84 , are identified by the franchisors as the most important problems. In the third position Insufficient financing sources, with an arithmetic mean of 2.40 , is designated. Quite close to the previous result, with an arithmetic mean of 2.33 , is the difficulty that banks and financial institutions fail to understand the franchising concept.

The conclusion is that that there are fundamental problems in respect of financing. The lack of sufficient financing sources was confirmed; also very few prospective entrepreneurs would not experience the problem of insufficient own capital. Only a few could generate capital on their own, have inherited large sums of money or received a substantial retirement endowment.

The problem regarding inadequate collateral also appears to be widespread. Banks and financial institutions set stringent requirements conceming collateral. They are risk averse and it is known practice that banks are more conservative in granting credit to new businesses than in the case of already established enterprises.

The foregoing response confirms the statement of government that a lack of access to financing is a significant constraint in the way of new and expanding small business enterprises.

\section{REFERENCES}

1 ANON. (1993) "Why Franchising Could be the Best Option", African Business and Chamber of Commerce Review.

2 BAUCUS, D.A., BAUCUS, M.S. \& HUMAN, S.E. (1993) "Choosing a Franchise: How Base Fees and Royalties Relate to the Value of the Franchise", Journal of Small Business Management, 31(2): 91-104.

3 CASTROGIOVANNI, G.J., JUSTIS, R.T. \& JULIAN, S.D. (1993) "Franchise Failure Rates: An Assessment of Magnitude and Influencing Factors", Journal of Small Business Management, 31(2): 105-15.

4 DE VILLIERS, T. (1994) "Fokus op Bedryfsreg", Finansies en Tegniek, 46(21): 49-58. 
5 GASKILL, L.R., VAN AUKEN, H.E. \& MANNING, R.A. (1993) “A Factor Analytic Study of Perceived Causes of Small Business Failure", Journal of Small Business Management, 31(4): 18-31.

6 GORDON, B. (2000) "The Franchise Factor 1999/2000": Fourth Survey on the Franchise sector in South Africa, Franchise Directions: Johannesburg.

7 HOLMES, M. (1994) "Spreading Your Wings", Financial Mail, 133(10). Supplement: Independent Business Opportunity: 27-30.

$8 \quad$ NTOULA, R. (1993) "The Franchising Highroad", African Business and Chamber of Commerce Review.

9 PARKER, E. \& GORDON, B. (1995) The Franchise Factor: First Formal FRANCHISE survey in South Africa, Johannesburg: Perskor.

10 RUITERS, A. (1996) "Government Strategies to Promote the Development of Small Business in South Africa, Accountancy and Finance Update, 1(2): 8-10.

11 THOMAS, W. (1995) "The SMME White Paper - Beginning of a New Era?" Southern African and Small Journal for Entrepreneurship Business, 7(1): 12-28. 